\title{
Choice of grazed herbage or maize silage by lactating dairy cows: influence of sward height and concentrate level
}

\author{
[Preferência por pastagem ou silagem de milho por vacas leiteiras em lactação: influência da altura \\ do pasto e do nível de concentrado] \\ O. Hernandez-Mendo ${ }^{1}$, J.D. Leaver ${ }^{2}$ \\ ${ }^{1}$ Programa de Ganaderia - Colegio de Postgraduados \\ Km 36.5 Carr. Mexico-Texcoco \\ Montecillo - Texcoco, Mexico 56230 \\ ${ }^{2}$ Retired Professor - Wye, Kent, UK
}

\begin{abstract}
The preference of lactating dairy cows for grazed herbage or maize silage (MS), simultaneously offered $a d$ libitum in the field, was examined at two sward heights (SH 4-6 and 8-10cm) and two concentrate levels (CL 0 and $6 \mathrm{~kg} \mathrm{day}^{-1}$ ) in a $2 \times 2$ factorial arrangement within a completely randomised experimental design. The experiment lasted 35 days and was carried out in spring using 24 multiparous Holstein Friesian cows. On average, the cows proportionately spent more time grazing than eating MS (0.85:0.15) and even though the higher rate of intake (RI) of dry matter (DM) of MS compared with grazed herbage (76 versus $26 \mathrm{~g} \mathrm{DM} \mathrm{min}^{-1}$ ), the proportion of total DM intake as herbage was higher compared to that of MS (0.56:0.44). The higher crude protein and low fibre content of grazed herbage appeared to have a higher priority of choice than RI, as the cows chose to graze for longer (grazing time $385 \mathrm{~min}$, MS feeding time $67 \mathrm{~min}$ ) despite the lower RI of herbage. The low proportion MS intake indicated that RI was a secondary factor of choice. Concentrate supplementation had a greater depressing effect on herbage intake than on MS intake. These results suggest that the animals reduce the intake of feed with lower RI when the labor associated to eat is decreased. The factors influencing the choice for herbage over maize silage remain unclear.
\end{abstract}

Keywords: milking cow, diet selection, concentrate, sward height

\section{RESUMO}

A preferência de vacas leiteiras em lactação por pasto ou silagem de milho (SM) oferecidas ad libitum simultaneamente no pasto foi avaliada quanto a duas alturas de pastagem $(4-6$ e $8-10 \mathrm{~cm})$ e dois níveis de concentrado $\left(0\right.$ e $\left.6 \mathrm{~kg} \mathrm{dia}^{-1}\right)$, em um arranjo fatorial $2 \times 2$ dentro de um delineamento inteiramente ao acaso. $O$ experimento, com duração de 35 dias, foi executado na primavera utilizando 24 vacas multíparas da raça Holandesa. As vacas passaram, em média, proporcionalmente mais tempo pastando do que comendo SM $(0,85: 0,15)$ e, mesmo considerando a maior taxa de consumo (TC) de matéria seca (MS) de SM comparada com a da pastagem (76 versus $26 \mathrm{~g} \mathrm{MS} \mathrm{min}^{-1}$ ), a proporção do total do consumo de MS como pastagem foi mais alta comparada com aquela da SM (0,56:0,44). A proteína crua mais alta e o menor conteúdo de fibra da pastagem pareceram ter prioridade na escolha pelos animais do que a TC, pois as vacas preferiram pastar por mais tempo (tempo de pastejo $=385 \mathrm{~min}$, tempo para comer $S M=67 \mathrm{~min}$ ), não obstante ter havido menor TC na pastagem. A baixa proporção de consumo de SM indicou que a TC foi um fator secundário na preferência dos animais. A suplementação concentrada teve maior efeito depressor no consumo de pastagem que o consumo de SM. Estes resultados sugerem que a prioridade dos animais, quando o trabalho associado com o comer é reduzido, é o de diminuir o consumo de alimento com menor TC. Os fatores que influenciaram a preferência por pastagem sobre silagem de milho ainda não são totalmente claros.

Palavras-chave: vaca leiteira, seleção da dieta, concentrado, altura da pastagem

Recebido em 23 de março de 2009

Aceito em 2 de agosto de 2010

Email: ohmendo@colpos.mx 


\section{INTRODUCTION}

Changing the proportion of time available to graze herbage or to eat maize silage offered indoors affects the relative intake of each feed, but the benefit to dairy cow performance of offering maize silage was only found to be significant when sward height was limiting (Hernandez-Mendo and Leaver, 2004; 2006). Behavioural observations showed that the rate of maize silage intake was considerably greater than for grazed grass, even though the nutritive value of the silage was lower.

Offering maize silage in the grazing paddock as an instantaneous alternative to grazing should give an insight into diet preference and provide a better understanding of the factors influencing feed intake. In practice, it may also provide a means of alleviating the high rate of decline in milk yield of 2-3\% per week of grazing dairy cows (Leaver, 1982), which is mainly due to low dry matter intake.

Time spent grazing appears to be the major factor affecting daily intake and preferences exhibited by ruminants in selecting a diet when grazing. Consequently, time spent grazing is of central importance to models of optimal diets, which assume that animals choose an optimal diet within sets of constrains (Rutter et al., 2004) including total feeding time, the digestive capacity of the animal, and the rate of intake. Under grazing conditions, these models are complex (Vazquez and Smith, 2001), as some of the variations in herbage intake results are due to sward conditions such as sward height, herbage availability, and the techniques used to measure herbage intake. Provenza (1996) reported that preferences are based on the functional interrelationship between taste and learned associations with post-ingestive feedback effects determined by the physiological condition of the animal and the chemical characteristics of the food. There is however a lack of information on the diet preferences of lactating dairy cows which have a high nutrient demand but a low rate of intake under grazing conditions (Pulido and Leaver, 2001). It is necessary to have an understanding of diet preferences in order to predict how much and from which diet animals select.
The objective of the study reported here was to investigate the diet choice of lactating dairy cows in spring when grazing and having simultaneously access to maize silage ad libitum in the field. Two sward heights and two concentrate levels were examined to assess whether these factors influenced choice of herbage or maize silage.

\section{MATERIAL AND METHODS}

The experiment was carried out from $30^{\text {th }}$ April to $4^{\text {th }}$ June 2001, at the Wye Dairy Research Unit ( $\left.5^{\circ} 10^{\prime} \mathrm{N}, 00^{\circ} 56^{\prime} \mathrm{E}\right)$, Imperial College, Ashford, Kent, UK.

Four treatments were allocated in a $2 \times 2$ factorial arrangement within a completely randomly experimental design with two replicates of each, with two concentrate $\left(0\right.$ and $\left.6 \mathrm{~kg} \mathrm{day}^{-1}\right)$ and two sward height $(4-6$ and $8-10 \mathrm{~cm})$ levels.

Twenty-four multiparous Holstein-Friesian cows were placed in eight groups of three cows each. The groups were balanced as closely as possible for milk yield, liveweight, condition score, parity, and days in milk, with respective initial means of milk yield of $27.4 \mathrm{~kg} \mathrm{day}^{-1}$ (range 15 $39.6 \mathrm{~kg} \mathrm{day}^{-1}$ ), liveweight of $562 \mathrm{~kg}$ (range 477 $718 \mathrm{~kg}$ ), body condition score of 1.9 (range 1.03.0 ), parity of 2.6 (range 2-4), and days in milk of 127 days (range 41-249 days). The eight groups were allocated at random to treatments.

The 4.2ha grazing area consisted of a predominantly perennial ryegrass (Lolium perenne L.) sward over 20 years of age, which had been subjected to continuously stocked management by dairy cows. It was divided into four similar-sized paddocks, and each one was subdivided into two sub-paddocks in a ratio of 1.0:1.5 to give the two sward height targets of 46 and $8-10 \mathrm{~cm}$, respectively. This sward height target was maintained on each paddock during the experimental period by moving the electric fence back or forward as required. The paddocks were grazed by a single group of dairy cows in the week prior to starting the experiment to achieve the target sward heights. The soil was a predominantly Wantage Series, grey rendinza soil characterized by a shallow, calcareous nature, with adequate water holding capacity to a depth of $30 \mathrm{~cm}$. The soil texture was a silty clay loam. The sward was fertilised with ammonium 
nitrate (34.5\% nitrogen) applied at a level of $40 \mathrm{~kg} \mathrm{~N} \mathrm{ha}^{-1}$ on $6^{\text {th }}$ March; $63 \mathrm{~kg} \mathrm{~N} \mathrm{ha}^{-1}$ on $2^{\text {nd }}$ April; and $55 \mathrm{~kg} \mathrm{~N}^{-1}$ on $7^{\text {th }}$ May. $\mathrm{P}$ and $\mathrm{K}$ indices were adequate with soil $\mathrm{pH}$ around 8.0.

The maize silage used in the experiment was made from the variety Botanis, which was ensiled in a clamp silo with no additive. The maize was sown on $10^{\text {th }}$ May and harvested on $19^{\text {th }}$ October 2000 , with no fertilizer, and cow slurry having been applied in the previous winter.

The concentrate contained $5.5 \mathrm{~kg}$ fresh weight of rolled barley plus $0.5 \mathrm{~kg}$ fresh weight of soyabean meal to produce an average of $160 \mathrm{~g}$ crude protein $(\mathrm{CP}) \mathrm{kg}^{-1} \mathrm{DM}$, and was offered in two equal amounts after each of the two milkings.

Fresh maize silage was offered ad libitum daily in the field in wooden bins with one in each paddock. The capacity of each bin was approximately $90 \mathrm{~kg}$ fresh matter, and had dimensions that allowed three cows to feed simultaneously. The amount of fresh maize silage offered varied according to the amount eaten on the previous day and considering $10 \%$ of refusals. The maize silage was daily put in the paddocks from 7:00-8:00h, whilst the cows were being milked. Refusals from the day before were weighed and sampled.

The paddocks were grazed continuously by the eight groups of cows. Within sward heights, the two replicates of the two concentrate level groups of cows were daily re-allocated to the paddocks, at random. The cows were put out to pasture from $8: 00$ to $14: 00 \mathrm{~h}$ and from $15: 00$ to $6: 00 \mathrm{~h}$. The remaining three hours daily were spent on morning and afternoon milking, and moving animals to and from the fields.

Sward height was measured twice weekly by using a rising plate meter made of aluminium, having sides of $31.5 \times 31.5 \mathrm{~cm}$ and exerting a pressure of $4.62 \mathrm{~kg} \mathrm{~m}$. On each occasion, 30 height measurements were taken in each paddock, at approximately $10 \mathrm{~m}$ intervals following a "W" pattern. Herbage mass was estimated at three sites selected to be high, medium, and low sward heights in each paddock on days 2 and 5, 16, and 19, and 30 and 33 of the experimental period. The samples were taken using a $31.5 \times 31.5 \mathrm{~cm}$ quadrat placed over the rising plate on each site of each paddock and cut to the ground level, after recording sward height. The cut samples were washed, oven dried for $48 \mathrm{~h}$ at $65^{\circ} \mathrm{C}$, and then weighed to estimate herbage mass. The samples were bulked for chemical analysis. A regression equation relating herbage mass to sward height across all the paddocks was estimated using samples from the whole experiment.

The herbage grazed by the cows was estimated by hand-plucking the herbage immediately adjacent to and at the height that cows were observed to graze. This was done from 8:00 to $13: 00 \mathrm{~h}$ on days $3,6,17,20,31$, and 34 of the experimental period. It was carried out by following one cow chosen at random in each paddock and plucking herbage from similar horizons, and at similar depth to that of the cow. The samples were weighed, then oven-dried for $48 \mathrm{~h}$ at $65^{\circ} \mathrm{C}$ and re-weighed. On each occasion, samples were bulked for subsequent chemical analysis.

Milk yield was daily automatically recorded at each milking for individual cows by a computerised recording system. Milk composition (fat, protein, and lactose) was recorded by analysing samples from individual cows by near infrared spectroscopy (NIR). Milk samples were taken during afternoon and morning milking on one day each week. Live weight was recorded by weighing cows twice per week after morning milking. Changes in liveweight were estimated by regression of the individual cow live weight over time for the experimental period. Body condition score was recorded weekly by using a 5-point scoring system (Wildman et al., 1982), in which a score of " 1 " represents an extremely thin cow and " 5 " represents an obese cow.

Grazing time (GT) and time spent eating maize silage (TSMS) were recorded during two 48-hour periods of observation at 10 and 15-minute intervals during the day (06:00-20:00h) and night (20:00-06:00h), respectively. This was done on days 11-13, and 25-26 of the experimental period, starting at 9:00 o'clock on day 1, and finishing at the same time on day 3 , to complete the 48-hour period. Observations were made individually for all cows, which were identified by large painted numbers on their sides. 
Proportion of feeding time as grazing was determined by considering GT+TSMS=feeding total time. Proportion of total DM intake as herbage was determined by considering Herbage DMI+Maize Silage DMI+Concentrate DMI $=$ Total DM intake.

Maize silage intake by group and concentrate intake by individual cows were taken by weighing the amount offered and the refused daily. Individual maize silage intake was estimated by partitioning the group intake to individuals according to their individual feeding times. Samples were dried in a forced air oven at $100^{\circ} \mathrm{C}$ in order to determine dry matter content, and at $65^{\circ} \mathrm{C}$ for chemical analysis. The dry matter of forages corrected for the loss of volatiles (CDM) was calculated from oven dry matter (ODM) using the following equation (AFRC, 1993):

$\mathrm{CDM}\left(\mathrm{g} \mathrm{kg}^{-1}\right)=0.99(\mathrm{ODM})+18.2$

Herbage dry matter intake was indirectly estimated from energy requirements according to AFRC (Energy..., 1993) from measured individual cow performance and $\mathrm{ME}$ concentration of the diet (grass, maize silage/soyabean meal, and concentrate according to treatments), using the following equation:

Herbage DM intake $\left(\begin{array}{ll}\mathrm{kg} & \text { day }^{-1}\end{array}\right)=$ (MEm+MEml+MElw+MEp-CoME) / Herbage ME

In which MEm+MEml+MElw+MEp are the individual metabolisable energy requirements for maintenance, milk (including adjusting for milk quality), liveweight change (corrected valueempty weight), and pregnancy, respectively. CoME is the energy supplied by the concentrate and maize silage/soyabean meal.

Analyses of feed samples included dry matter and total ash according to AOAC (Official..., 1980), in vitro neutral cellulase and gammanase digestibility (NCGD) (Prediction..., 1993), crude protein (CP) (Cullison and Lowrey, 1987), neutral detergent fibre (NDF) and starch (not herbage) (Aman and Hesselman, 1984), acid detergent fibre (ADF), and ether extract (EE) (The analysis..., 1986). In addition, maize silage, pH (The analysis..., 1986), volatile fatty acids (lactic, acetic, and butyric) (Fussel and
McCalley, 1987), ethanol, and ammonia nitrogen $\left(\mathrm{NH}_{4} \mathrm{~N}\right)$ (Boisen et al., 1987) were measured.

The data were analysed using a $2 \times 2$ factorial arrangement within a completely randomised design. Concentrate supplementation and sward height were the independent variables with group of three cows used as replicates. This was carried out using the ANOVA procedure of GENSTAT version 5 (Lane and Payne, 1997) with covariance analysis for animal production results using initial (a week prior starting the experiment) milk yield, milk composition, live weight, and score condition values as covariates. Interactions were tested, but they were not significant. Individual cow results were used as statistical unit in the analysis, and even though some facilitation of feeding behaviour between cows may have occurred, more replications of treatment groups was not feasible in an experiment of this size. Chemical composition data were analysed as completely randomised design.

Temperature and precipitation data were taken from the Meteorological Station at Wye. Mean daily maximum and minimum temperatures were 16.9 and $8.3^{\circ} \mathrm{C}$, respectively, and mean rainfall was $1.6 \mathrm{~mm}$ day $^{-1}$.

\section{RESULTS AND DISCUSSION}

Sward heights remained within the target range throughout the experimental period, averaging $5.9(\mathrm{SEM} \pm 0.107)$ and $8.9(\mathrm{SEM} \pm 0.165) \mathrm{cm}$ on the low and high sward heights, respectively. The linear regression equation of sward height $(\mathrm{SH} \mathrm{cm})$ on herbage mass (HM kg DM ha ${ }^{-1}$ ) was:

$\mathrm{HM}=180( \pm 16.0)+267( \pm 24.7) \mathrm{SH}, \quad \mathrm{r}^{2} 0.83$

Mean herbage mass estimated from the regression equation was 1,759 and $2,562 \mathrm{~kg}$ DM $\mathrm{ha}^{-1}$ at low and high sward height, respectively. There were significant differences in chemical composition between herbage offered (ground level samples) and simulated (plucked) grazing samples but not between sward heights (Table 1). The maize silage and barley/soyabean concentrate chemical composition are presented in Table 2. The average $\mathrm{CP}$ of the barley/soyabean concentrate was $151 \mathrm{~g} \mathrm{~kg}^{-1} \mathrm{DM}$, slightly lower than the target content of $160 \mathrm{~g} \mathrm{CP}$ $\mathrm{kg}^{-1} \mathrm{DM}$. 
Table 1. Composition of herbage offered (HO, ground level samples) and grazed (HG, plucked samples) at different sward heights $\left(\mathrm{g} \mathrm{kg}^{-1} \mathrm{DM}\right.$ except where stated)

\begin{tabular}{lrrrrrrrr}
\multirow{2}{*}{ Parameter } & \multicolumn{2}{c}{$\begin{array}{c}\text { Herbage } \\
\text { offered }\end{array}$} & \multicolumn{1}{c}{ Herbage grazed } & \multicolumn{2}{c}{ HO/HG } & \multicolumn{2}{c}{ Sward height } \\
\cline { 2 - 10 } & \multicolumn{1}{c}{ LSH } & \multicolumn{1}{c}{ HSH } & \multicolumn{1}{c}{ LSH } & \multicolumn{1}{c}{ HSH } & \multicolumn{1}{c}{ s.e.d. } & \multicolumn{1}{l}{ sig. } & \multicolumn{1}{c}{ s.e.d. } & \multicolumn{1}{l}{ sig. } \\
\hline DM $\left(\mathrm{g} \mathrm{DM} \mathrm{kg}^{-1}\right)$ & 206 & 207 & 194 & 191 & 3.0 & 0.001 & 4.4 & 0.743 \\
Ash & 115 & 102 & 101 & 99 & 6.4 & 0.173 & 9.1 & 0.509 \\
Crude protein & 165 & 167 & 221 & 224 & 7.3 & 0.001 & 10.7 & 0.814 \\
NDF & 556 & 515 & 479 & 464 & 23.9 & 0.020 & 34.9 & 0.491 \\
ADF & 282 & 262 & 226 & 224 & 13.9 & 0.005 & 20.4 & 0.668 \\
NCGD & 717 & 758 & 831 & 840 & 15.5 & 0.001 & 21.0 & 0.405 \\
ME (MJ kg $\left.{ }^{-1} \mathrm{DM}\right)$ & 11.20 & 11.65 & 12.46 & 12.56 & 0.172 & 0.001 & 0.233 & 0.405 \\
\hline
\end{tabular}

NDF, neutral detergent fibre; ADF, acid detergent fibre; NCGD, neutral cellulase, and gammanase digestibility; ME, metabolisable energy; LSH, low sward height $(4-6 \mathrm{~cm})$; HSH, high sward height $(8-10 \mathrm{~cm})$; s.e.d., standard error deviation.

Table 2. Composition of maize silage, barley, soyabean meal, and barley/soyabean mixture $\left(\mathrm{g} \mathrm{kg}^{-1} \mathrm{DM}\right.$ except where stated)

\begin{tabular}{|c|c|c|c|c|c|c|c|}
\hline \multirow{2}{*}{ Parameter } & \multicolumn{2}{|c|}{ Maize silage } & \multicolumn{2}{|c|}{ Barley (B) } & \multicolumn{2}{|c|}{ Soyabean meal (sb) } & \multirow{2}{*}{$\mathrm{B} / \mathrm{sb}$} \\
\hline & mean & s.e.m. & mean & s.e.m. & mean & s.e.m. & \\
\hline Oven DM(g DM kg $\left.{ }^{-1}\right)$ & 330 & 3.0 & 880 & 0.7 & 900 & 1.1 & 882 \\
\hline Ash & 41 & 1.3 & 30 & 2.8 & 73 & 0.3 & 34 \\
\hline Crude protein & 80 & 2.6 & 118 & 2.8 & 481 & 6.3 & 151 \\
\hline $\mathrm{NDF}$ & 466 & 3.6 & 234 & 5.6 & 134 & 5.2 & 225 \\
\hline $\mathrm{ADF}$ & 250 & 3.4 & 96 & 2.6 & 86 & 1.7 & 95 \\
\hline NCGD & 743 & 4.3 & 876 & 12.4 & 916 & 2.5 & 880 \\
\hline $\mathrm{ME}\left(\mathrm{MJ} \mathrm{kg}^{-1} \mathrm{DM}\right)$ & 11.05 & 0.043 & 12.88 & 0.137 & 13.16 & 0.027 & 12.90 \\
\hline Ether extract & 26 & 3.0 & 25 & 1.7 & 13 & 0.7 & 24 \\
\hline Starch & 283 & 30.0 & 568 & 1.7 & 4 & 0.5 & 520 \\
\hline $\mathrm{pH}$ & 3.6 & 0.03 & & & & & \\
\hline Ethanol & 11 & 3.0 & & & & & \\
\hline Acetic acid & 32 & 4.3 & & & & & \\
\hline Propionic acid & $<10$ & 0 & & & & & \\
\hline Butyric acid & $<10$ & 0 & & & & & \\
\hline Lactic acid & 90 & 2.4 & & & & & \\
\hline
\end{tabular}

NDF, neutral detergent fibre; ADF, acid detergent fibre; NCGD, neutral cellulase and gammanase digestibility; ME, metabolisable energy; s.e.m., standard error of the mean.

There were no significant interactions between concentrate and sward height on animal behaviour measurements.

The herbage and total DM intake were higher $(\mathrm{P}<0.05)$ at high sward height, while the maize silage DM intake was higher $(\mathrm{P}<0.01)$ at the low sward height. Only herbage DM intake was affected by concentrate level, being higher with no concentrate (Table 3). Concentrate decreased estimated herbage dry matter intake by 0.75 and $1.04 \mathrm{~kg}$ DM, at low and high sward height, respectively. The proportion of total DM intake as herbage was significantly affected $(\mathrm{P}<0.05)$ by both sward height and concentrate level, being higher at the high sward height and with no concentrate.

Grazing time, maize silage feeding time, and proportion of feeding time as grazing were not affected $(\mathrm{P}>0.05)$ by either sward height or concentrate level, except grazing time that increased $(\mathrm{P}<0.05)$ with no concentrate. Concentrate decreased grazing time by 4.3 and 12.5 minutes day ${ }^{-1} \mathrm{~kg}^{-1}$ concentrate DM at low and high sward heights, respectively. 
Table 3. Effect of two concentrate levels and two sward heights on estimated dry matter intake (DMI) and feeding behaviour of lactating dairy cows when grazing and having simultaneously access to maize silage in the field

\begin{tabular}{|c|c|c|c|c|c|c|c|}
\hline \multirow{4}{*}{ Parameter } & \multicolumn{4}{|c|}{ Sward height (SH, cm) } & \multirow{4}{*}{ s.e.d. } & \multirow{3}{*}{\multicolumn{2}{|c|}{ significance }} \\
\hline & & & & & & & \\
\hline & \multicolumn{4}{|c|}{ Concentrates $\left(\mathrm{C}, \mathrm{kg}\right.$ day $\left.^{-1}\right)$} & & & \\
\hline & 0 & 6 & 0 & 6 & & $\mathrm{SH}$ & $\mathrm{C}$ \\
\hline Herbage DMI (kg day $\left.{ }^{-1}\right)$ & 10.7 & 6.7 & 13.9 & 8.4 & 0.81 & 0.013 & 0.001 \\
\hline Maize silage DMI $\left(\mathrm{kg} \mathrm{day}^{-1}\right)$ & 6.1 & 5.2 & 4.6 & 4.3 & 0.37 & 0.009 & 0.088 \\
\hline Total DMI (kg day $\left.{ }^{-1}\right)$ & 16.8 & 17.2 & 18.5 & 18.0 & 0.49 & 0.026 & 0.828 \\
\hline $\begin{array}{l}\text { Proportion of total DMI as } \\
\text { herbage }\end{array}$ & & & & & & & \\
\hline herbage & 0.64 & 0.39 & 0.75 & 0.47 & 0.055 & 0.010 & 0.011 \\
\hline Grazing time $\left(\min\right.$ day $\left.^{-1}\right)$ & 401 & 378 & 413 & 347 & 14.1 & 0.398 & 0.011 \\
\hline Maize silage FT $\left(\min\right.$ day $\left.^{-1}\right)$ & 77 & 76 & 61 & 55 & 10.2 & 0.063 & 0.658 \\
\hline Proportion of FT as grazing & 0.84 & 0.83 & 0.87 & 0.86 & 0.050 & 0.230 & 1.000 \\
\hline RI herbage $\left(\mathrm{g} \mathrm{DM} \mathrm{min}^{-1}\right)$ & 26.4 & 17.9 & 33.9 & 24.2 & 0.94 & $<0.001$ & $<0.001$ \\
\hline RI maize silage (g DM $\left.\min ^{-1}\right)$ & 79.2 & 69.1 & 75.7 & 79.0 & 10.6 & 0.691 & 0.673 \\
\hline
\end{tabular}

FT, feeding time; RI, rate of intake; s.e.d., standard error deviation.

Interactions between $\mathrm{SH}$ and $\mathrm{C}$ were not significant.

The rate of herbage intake was higher $(\mathrm{P}<0.001)$ at high sward height and with no concentrate. Concentrate decreased rate of herbage intake by 1.6 and $1.8 \mathrm{~g} \mathrm{DM} \min ^{-1} \mathrm{~kg}^{-1}$ concentrate $\mathrm{DM}$ at low and high sward heights, respectively. However, the rate of maize silage intake was not affected neither by sward height nor by concentrate level.

There were no significant interactions between sward height and concentrate for any dairy cow performance measurements.
Milk yield and milk constituents were not affected by concentrate level (Table 4), but milk yield, fat yield, and lactose yield were affected $(\mathrm{P}<0.05)$ by sward height, with greater values at the high sward height. Milk yield decline was not affected by sward height but by concentrate level $(\mathrm{P}<0.01)$, decreasing $0.02 \mathrm{~kg} \quad \mathrm{day}^{-1} \quad \mathrm{~kg}^{-1}$ concentrate DM.

Live-weight and condition score were not affected neither by sward height nor by concentrate level.

Table 4. Effect of two concentrate levels and two sward heights on dairy cow performance when grazing and having simultaneously access to maize silage in the field

\begin{tabular}{|c|c|c|c|c|c|c|c|}
\hline \multirow{4}{*}{ Parameter } & \multicolumn{4}{|c|}{ Sward height $(\mathrm{SH}, \mathrm{cm})$} & \multirow{4}{*}{ s.e.d. } & \multirow{3}{*}{\multicolumn{2}{|c|}{ significance }} \\
\hline & & & & & & & \\
\hline & \multicolumn{4}{|c|}{ Concentrates $\left(\mathrm{C}, \mathrm{kg} \mathrm{day}^{-1}\right)$} & & & \\
\hline & 0 & 6 & 0 & 6 & & $\mathrm{SH}$ & $\mathrm{C}$ \\
\hline Milk yield (kg day $\left.{ }^{-1}\right)$ & 23.6 & 25.5 & 26.6 & 26.0 & 0.58 & 0.013 & 0.161 \\
\hline Fat yield $\left(\mathrm{kg} \mathrm{day}^{-1}\right)$ & 0.85 & 0.90 & 1.05 & 0.95 & 0.061 & 0.045 & 0.595 \\
\hline Protein yield $\left(\mathrm{kg}\right.$ day $\left.^{-1}\right)$ & 0.80 & 0.90 & 0.90 & 0.90 & 0.071 & 0.374 & 0.374 \\
\hline Lactose yield $\left(\mathrm{kg}\right.$ day $\left.^{-1}\right)$ & 1.05 & 1.15 & 1.30 & 1.20 & 0.050 & 0.013 & 0.899 \\
\hline Milk fat $\left(\mathrm{g} \mathrm{kg}^{-1}\right)$ & 36.1 & 35.3 & 39.8 & 35.9 & 3.03 & 0.373 & 0.335 \\
\hline Milk protein $\left(\mathrm{g} \mathrm{kg}^{-1}\right)$ & 33.7 & 34.5 & 35.0 & 35.0 & 1.39 & 0.411 & 0.705 \\
\hline Milk lactose $\left(\mathrm{g} \mathrm{kg}^{-1}\right)$ & 44.1 & 44.6 & 47.4 & 45.7 & 1.89 & 0.178 & 0.689 \\
\hline Milk yield decline $\left(\mathrm{kg} \mathrm{day}^{-1}\right)$ & 0.20 & 0.10 & 0.20 & 0.05 & 0.035 & 0.374 & 0.007 \\
\hline Mean live weight $(\mathrm{kg})$ & 578 & 580 & 580 & 586 & 8.5 & 0.484 & 0.316 \\
\hline Live-weight gain $\left(\mathrm{kg} \mathrm{day}^{-1}\right)$ & 1.1 & 1.3 & 1.4 & 1.4 & 0.103 & 0.165 & 0.292 \\
\hline Mean condition score & 2.0 & 1.75 & 1.70 & 1.95 & 0.132 & 0.621 & 1.000 \\
\hline
\end{tabular}

Interactions between SH and C were not significant; s.e.d., standard error deviation. 
In this study, it was observed that cows showed active selection for grazing to maize silage as shown by the higher proportion of feeding time as grazing, as well as the higher proportion of total DM intake as herbage (Table 3).

Provenza et al. (1996) stated that preference is influenced by the quality of feeds. In this study, the herbage had a higher digestibility than the maize silage (NCGD 835 versus $743 \mathrm{~g} \mathrm{~kg}^{-1} \mathrm{DM}$ ), ME (12.52 versus $\left.11.05 \mathrm{MJ} \mathrm{kg}^{-1} \mathrm{DM}\right)$, and crude protein content ( 222 versus $\left.80 \mathrm{~g} \mathrm{~kg}^{-1} \mathrm{DM}\right)$, which might have been a priority of choosing herbage over maize silage.

Keeping a balance between CP and energy is one of the most important ruminant objectives (Early and Provenza, 1998), since it has to achieve a satisfactory energy and protein intake under natural circumstances in order to maintain the rumen as a functional organ. This suggests that in the present study, offering mixed diet (grazed herbage and maize silage, simultaneously) to lactating dairy cows led to an increase in the efficiency of the digestion of the DM, as there is a better proportion of the microorganisms in the rumen compared with animals that eat only one kind of feed, as stated by Rutter et al. (2004).

The choice for herbage over maize silage occurred in spite of the higher rate of intake of maize silage compared with herbage (76 versus $26 \mathrm{~g} \mathrm{DM} \mathrm{min}^{-1}$ ). This is opposite to that found by Rutter et al. (2004), who explained that dairy cows preferred clover over grass because of the higher intake rate of clover. Thus, the cows in the present study might have maximized either diet quality or DM intake by mainly selecting grass. It could be concluded that the choice for herbage was clearly demonstrated by the additional time spent grazing compared with eating maize silage (385 versus 67 min day $^{-1}$ ). However, it is not clear which factors were driving it.

It has been reported that DM intake is positively correlated with DM content, but in this study, although maize silage had a higher DM content than the herbage, it was consumed as a smaller proportion of the diet. In addition, Phillips and Youseff (2003) reported that a previous experience exerts an influence on preference and consequently there may be a reluctance to eat under novel environments. Then it is possible that the maize silage, offered in the field, represented a new environment for the cows in the present study, causing a reluctance to eat, although there was no evidence of this.

The proportion of maize silage intake was higher after morning milking compared with the rest of the day. This suggests that offering fresh maize silage more than once per day could increase daily intake. It is also possible that after morning milking cows were experiencing hunger and overcame this by choosing maize silage due to its high rate of intake and so they could eat it quickly.

Given the range of factors that can affect how cows respond to diet choices, we urge caution in extrapolating the results from the current study to other situations. It is possible that sufficiently well designed feeding maize silage conditions, or sufficiently poor sward conditions, could increase preference for maize silage or even reverse the results reported here. Besides, the method used to estimate the herbage dry matter intake could be not the most appropriate given the complexity of this study, and the herbage DM intake, might have been under-estimated particularly at high level of concentrate, and the substitution rate over-estimated. However, to the knowledge of the authors, this is the first such test addressing preference to different feeds during grazing of lactating dairy cows, and indeed it is an aim to continue to improve such methodology to estimate DM intake at pasture to better understand the motivation of grazing cows in selecting their diet when having access to different feeds.

In this research, the proportion of herbage grazed increased with sward height from 0.60 to 0.68 , but not significantly, however, rate of herbage intake was $1.7 \mathrm{~g} \mathrm{DM} \mathrm{min}^{-1} \mathrm{~cm}^{-1}$, significantly greater on the high sward height (Table 3).This value is a bit higher to those recorded by Barret et al. (2001), who found an increase of $1.5 \mathrm{~g} \mathrm{DM}$ $\min ^{-1} \mathrm{~cm}^{-1}$ in autumn but not in spring without access to any roughage or concentrate. This suggests that the choice with grazing animals is considered to depend on grass availability and accessibility, as stated by Barret et al. (2001).

When concentrates were offered, the choice for grazed herbage decreased from a ratio of 0.70 to 0.43 , which meant that for each $\mathrm{kg}$ of concentrate DM, herbage intake decreased about $0.90 \mathrm{~kg}$ DM 
day $^{-1}$. This high substitution rate is thought to be due to a diminished rate of cellulose digestion in the rumen, and a reduced rate of passage of digesta (Russell et al., 1992). And even though, under grazing conditions, cows rarely eat until the rumen is full. Maize silage intake contributed to this rumen effect, as it remained similar with or without concentrate. This might explain why concentrate reduced herbage intake in a high proportion. Besides, as discussed before, it is possible that the method used to estimate the DM intake might have underestimated it, as the concentrate might have decreased the actual digestibility of herbage and maize silage. It is interesting to observe that even though concentrate decreased choice for herbage, the proportion of choosing it remained high (0.43) compared to maize silage $(0.27)$ and the concentrate itself (0.30). In this experiment, concentrate significantly depressed grazing time more than maize silage feeding time, which indicates that the cows chose to prioritise a reduction in feeding time of the feed (in this case herbage) with the lowest rate of intake, probably due to its associated higher energy requirement of harvesting per $\mathrm{kg}$ DM.

Although this discussion has focussed on why lactating dairy cows chose grazing over maize silage in the field, at different sward height and concentrate level, such management also exposes cows to a change diet, and this too might have affected the cow performance. However, the results reported here showed that only milk yield, fat and, lactose yield were affected by sward height, being higher at the high sward height level. It was also found that milk yield decline was affected by concentrate level, being higher on cows without concentrate. In fact, milk decline was maintained even on those cows with concentrate. It can be argued that although concentrate was provided to grazing cows, the decreased nutrient density of the DM consumed (relative to the indoor feeding) was expected to reduce energy intake, accounting for the changes in bodyweight and milk yield. The magnitude of such changes will vary in relation to grazing conditions and feed management.

\section{CONCLUSIONS}

Under spring grazing conditions, cows demonstrated a clear preference for grazed herbage compared with eating maize silage by spending proportionately more time grazing than eating maize silage, and although the rate of intake of grazed herbage was lower, the cows consumed a higher proportion of herbage than maize silage dry matter. However, the factors affecting the results showed here remain unclear and indeed warrants further testing. Indeed it is an aim for future research projects to clarify all the questions that came out.

\section{REFERENCES}

AMAN, P.; HESSELMAN, K. Analysis of starch and other main constituents of cereal grain. Swed. J. Agric. Res., v.14, p.135-139, 1984.

BARRETT, P.D.; LAIDLAW, A.S.; MAYNE, C.S. et al. Pattern of herbage intake rate and bite dimensions of rotationally grazed dairy cows as sward height declines. Grass Forage Sci., v.56, p.362-373, 2001.

BOISEN, S.; BENCH-ANDERSEN, S.; EGGUM, B.O. A critical view on the conversion factor 6.25 from total nitrogen to protein. Acta Agric. Scand., v.37, p.299-304, 1987.

CULLISON, A.E.; LOWREY, R.S. (Eds). Feeds and feeding. 4.ed. London: Englewood Cliffs Reston, 1987.

EARLY, D.M.; PROVENZA, F.D. Food flavor and nutritional characteristics alter dynamics of food preferences in lambs. J. Anim. Sci., v.76, p.728-734, 1998.

ENERGY and protein requirements of ruminants. Wallingford, UK: CAB International, 1993.

FUSSEL, R.J.; McCalley, D.V. Determination of volatile fatty acids (C2-C5) and lactic acid in silage by gas chromatography. Analyst, v.112, p.1213-1216, 1987.

HERNANDEZ-MENDO, O.; LEAVER, J.D. Production and behavioural responses of highand low-yielding dairy cows to different periods of access to grazing or to a maize silage and soyabean meal diet fed indoors. Grass Forage Sci., v.61, p.335-346, 2006. 
HERNANDEZ-MENDO, O.; LEAVER, J.D. Effect of replacing time available for grazing with time available for eating maize silage and soyabean meal on milk yield and feeding behaviour in dairy cows. Grass Forage Sci., v.59, p.318-330, 2004.

LANE, P.W.; WAYNE, R.W. An introductory course for GENSTAT 5 release 4. Rothamsted Experimental Station. Oxford: Numerical Algorithms Group, 1997.

LEAVER, J.D. Grass height as an indicator for supplementary feeding of continuously stocked dairy cows. Grass Forage Sci., v.37, p.285-290, 1982.

OFFICIAL methods of analysis. 13.ed. Washington, DC: AOAC, 1980. 1018p.

PHILLIPS, C.J.C.; YOUSEFF, M.Y.I. The effect of previous experience of four pasture experience on the grazing behaviour on ewes and their lambs. Anim. Sci., v.77, p.329-333, 2003.

PREDICTION of energy value of compound foodstuffs for farm animals. Alnwick, UK: MAFF Publications, 1993. (booklet 1285).

PROVENZA, F.D. Acquired aversions as the basis for varied diets for ruminants foraging on rangelands. J. Anim. Sci., v.74, p.2010-2020, 1996.
PROVENZA, F.D.; SCOTT, C.B., PHY, T.S. et al. Preference of sheep for foods varying in flavours and nutrients. J. Anim. Sci., v.74, p.2355-2361, 1996.

PULIDO, R.G.; LEAVER, J.D. Quantifying the influence of sward height, concentrate level and initial milk yield on the milk production and grazing behaviour of continuously stocked cows. Grass Forage Sci., v.56, p.57-67, 2001.

RUSSELL, J.B.; O' CONNOR, J.D.; FOX, D.G. et al. A net carbohydrate and protein system for evaluating cattle diets: I. Ruminal fermentation. J. Anim. Sci., v.70, p.3551-3561, 1992.

RUTTER, S.M.; ORR, R.J.; YARROW, N.H. et al. Dietary preference of dairy cows grazing ryegrass and white clover. J. Dairy Sci., v.87, p.1317-1324, 2004.

THE ANALYSIS of agricultural materials. London: MAFF - Her Majesty's Stationery Office, 1986. (book 427).

VAZQUEZ, O.P.; SMITH, T.R. Evaluation of alternative algorithms used to simulate pasture intake in grazing dairy cows. J. Dairy Sci., v.84, p.860-872, 2001.

WILDMAN, E.E.; JONES, G.M.; WAGNER, P.E. et al. A dairy cow body condition scoring system and its relationship to selected production characteristics. J. Dairy Sci., v.65, p.495-501, 1982. 